\title{
Study Of Recreational Waterfront Area Development A Case Study: Ujong Blang Beach, Lhokseumawe City
}

\author{
Nasruddin ${ }^{1}$,Nurlisa Ginting ${ }^{2} \&$ Hilma Tamiami Fachrudin ${ }^{3}$ \\ \{nass_arch@yahoo.co.id ${ }^{\mathbf{1}}$, nurlisa.ginting@gmail.com², hilma@usu.ac.id ${ }^{3}$ \} \\ ${ }^{1}$ Student of Master Degree Program of Architecture Department, Faculty of Engineering. Perpustakaan \\ Street J7 Building, Universitas Sumatera Utara, Medan,Indonesia 20155 \\ ${ }^{2,3}$ Lecturer of Master Degree Program of Architecture Department, Faculty of Engineering. Perpustakaan \\ Street J7 Building, Universitas Sumatera Utara, Medan, Indonesia 20155
}

\begin{abstract}
Indonesia is an archipelago which has a long coastline. The coastal tourism in Indonesia is very potential to be developed. Therefore, it needs to be planned and developed in order to improve the city development. The tourism sector has important values and contributions with broad dimensions, economically, socially, politically, culturally, regionally and environmentally. The purpose of this study was to analyze the physical and non-physical aspects, and aspects of facilities needed for the development of waterfront recreational area in the city of Lhokseumawe. This study promotes the study of important aspects that need to be considered in the development of tourism areas, especially coastal tourism areas. The research was conducted by mixing descriptive qualitative methods and descriptive statistics. The results of this study were expected to be the input to tourism area planning, especially in Lhokseumawe City and Indonesia in general, in order to increase regional development, especially from the waterfront recreational/tourism sector. The conclusion of the study is expected to be the guidelines relating to the development of physical and non-physical aspects, and aspects of facilities of the regional area in order to increase the economic growth.
\end{abstract}

Keywords: Area development, Recreational Waterfront, tourism

\section{Introduction}

The tourism sector is a sector that needs to be developed for regional development. Development in the tourism sector will affect several other sectors such as transportation, accommodation and trade. Tourism is one of the new industries that is able to help rapid economic growth in providing employment, raising living standards, and stimulating other productivity sectors. Tourism is related to other supporting fields. The influence caused by tourism includes expanding business opportunities, opening employment opportunities, increasing public and government incomes, and encouraging improvements in other sectors. Tourism is a very strategic industrial sector, because it is able to open business opportunities that can be managed by the community to improve their quality of life [1]. One of the types of tourism is waterfront tourism. The existence of an area on the edge of the water can be used for the development and development of cities, including for ports, fisheries, tourism, and other maritime-based potentials. The waterfront area has a characteristic that is different from other types of topographic land surface. Waterfront is a place where land and water meet. The 
purpose of this study is to formulate the concept of recreational waterfront in the aspect of development for the Ujong Blang Beach waterfront tourism destination and analyze tourist perceptions of the existing conditions of Ujong Blang Beach tourism and its development. The city of Lhokseumawe is one of the cities located in Aceh Province, which is located on the northern coast, and directly borders the Malacca Strait. Seeing the existence of the geographical location of the City of Lhokseumawe which is adjacent to the coast, this city can be categorized as Waterfront City. The existence of waterfront tourism in the city of Lhokseumawe is currently not organized and generally still managed privately by the people around the tourist attraction. Based on this, it would be appropriate to develop a waterfront tourism area in Lhokseumawe City. The existence of a waterfront area can be used for urban development. The existence of these tourist areas also has economic value because of the development of waterfront infrastructure facilities. Another factor is that the declining regional income of Lhokseumawe City from the oil and gas sector will affect regional income, therefore it is necessary to develop sources of income from other sectors such as agriculture, tourism, trade and services.

Based on the meeting of the water body, there are 3 types of waterfronts: 1) Waterfront of riverside, 2) Waterfront of bay and ocean, and 3) Waterfront of lake. The city area on the water's edge is called waterfront city [2]. Whereas according to Breen, waterfront is a dynamic area which is a place where land and water meet. The waterfront area is divided into several aspects. Based on its function aspects, waterfront can be divided into 4 types, namely: 1) mixed-used waterfront, 2) recreational waterfront, 3) residential waterfront, and 4) working waterfront. While based on the type of coastal development, waterfront can be divided into 4 types, namely: 1) conservation or structuring the historic area, 2) preservation or the preservation of historic areas, 4) redevelopment or rebuilding and 5) development [3]. In this study, the aspect of waterfront function is recreational waterfront, which is the function of the waterfront area for tourism purposes. Etymologically, recreation is taken from Latin, namely "re" and "create". The meaning is to recreate, then recreation is an activity that aims to refresh one's body and spirit after working everyday.

The success of the development of waterfront areas is determined by planning in response to the characteristics / uniqueness of the waterfront area. Characteristics are divided into two, namely physical and non-physical. Physical characteristics include the state of nature and the environment, image of access, buildings, landscape arrangement, availability of urban facilities and infrastructure and technological advancements. While non-physical characters are the theme of development, water utilization, population activities, social conditions, culture, economy, regulation and management of cities / regions [4].

\section{Method}

The research method used is a mixed method, qualitative and quantitative. The analysis of qualitative data was carried out by using qualitative description whereas quantitative data analysis was carried out by using descriptive statistics. The data collection was carried out by observing the field at Ujong Blang beach and interviewing village heads and stakeholders from four villages namely Ujong Blang village, Ulee Jalan village, Hagu Barat Laut village and Hagu Tengah village. In addition, interviews were also conducted with the Head of the Tourism Office, the Public Works Service and the Lhokseumawe City Development Planning Agency. The tourist perception data was obtained by distributing questionnaires to 100 
respondents with accidental sampling method. Questionnaire assessment was carried out by using a likert scale and the preparation of questionnaire data was done on a numerical scale by dividing the scale range [5]. The value of the scale range is 80 namely: a score of $100-180$ is categorized as poor, 180.1-260 is bad, 260.1-340 is fair, 340.1-420 is good, and 420.1-500 is excellent. The research was located on the beach of Ujong Blang, Lhokseumawe City, Aceh Province, Indonesia. The city of Lhokseumawe is a coastal area that is directly adjacent to the Malacca Strait with an area of $181.06 \mathrm{~km} 2$. Ujong Blang Beach has a length of approximately 4 (four) kilometers which is located in Banda Sakti District which is directly adjacent to the Malacca Strait. Ujong Blang Beach is listed as the location of tourist attraction in the city of Lhokseumawe [6].

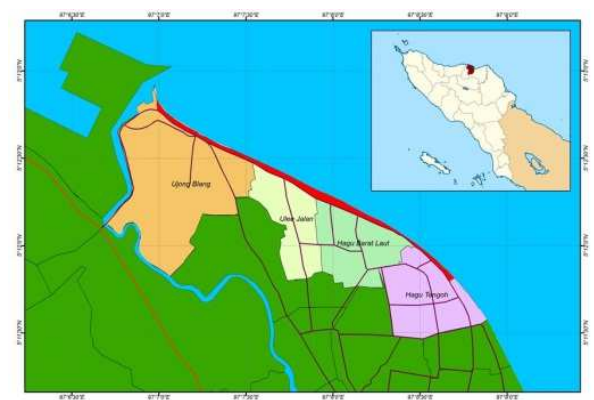

Fig. 1. The Location of Ujong Blang Beach in the City of Lhokseumawe, Aceh Province, Indonesia

\section{Result and Discussion}

\subsection{Physical Aspects}

Physical and environmental aspects are related to the existence of the image, proportion and aesthetics of the location so that it attracts tourists to visit the area. From the physical and coastal aspects, Ujong Blang has a relatively sloping land with shallow edges so that visitors can relax and take a walk along the waterfront. The northern part of the beach has a sandy surface while in the south part, there are rocks that function as breakers to avoid abrasion. The coastline of Ujong Blang is generally a fishing settlement, at certain times, visitors can see fishermen using trawler, a traditional tool to catch fish. This activity can be an attraction for visitors. Visitors play the sand on the beach with the family. The asphalt road on the beach extends to follow the shoreline with a distance of 100-150 meters from the shoreline. The results of the questionnaire respondents' assessment of the physical aspects on the coast of Ujong Blang are as shown below.

Table 1. Respondents' assessment on the physical aspects

\begin{tabular}{clc}
\hline No. & Variables & Score \\
\hline 1 & Image/attraction of the location & 362 \\
\hline 2 & Condition of the Environment & 251 \\
\hline 3 & State of the Landscape & 378 \\
\hline 4 & Existing Landscape Arrangement & 237 \\
\hline 5 & Existing Building Arrangement & 233 \\
\hline & Total & 1461 \\
\hline
\end{tabular}


Based on the respondents' assessment of the physical aspects of the five elements that are assessed, the element of the environment, the existing landscape and the arrangement of the building have low scores. This is due to the low awareness in maintaining environmental cleanliness, the uneven greening of the vegetation and the buildings that have not been arranged or planned well on the Ujong Blang beach. Based on interviews with the Head of the Lhokseumawe City Tourism Office, the construction of the Ujong Blang beach will be carried out in the form of the addition of jogging tracks, green parks, public toilets, and art performances. The development aims to develop the coastal tourism area of Ujong Blang by completing infrastructure facilities for the needs of the visitors of the tourism area. The physical character is one aspect of the development of a water tourism area which includes the state of nature and environment, the image of access, building and landscape arrangement, availability of facilities and infrastructure of the city [4].

\subsection{Facility Aspects}

Tourist facilities can be interpreted as facilities and infrastructure available to be used by visitors in tourism area. Visitors need not only enjoy the beauty of nature or the uniqueness of attractions, but also the facilities and infrastructure of accomodation, transportation, and other supporting facilities. Facilities to reach tourist locations can be in the form of road access, inns/ hotels, restaurants, and culinary. Road facilities are already available at Ujong Blang Beach, which is a two-lane city ring road. There are public toilet facilities and along the shore, there are culinary lodges so that visitors can enjoy local food such as rujak and mie Aceh. There is a health facility in the form of Community Health Centers (Puskesmas) which are open 24 hours. There are also facilities for visitors to have fun, namely speed boats, banana boats and lifebuoy/ swimming tire rentals. Relating to the road facilities, based on the results of interviews with the Public Works Service, the ring road built has not finished yet. When it has been finished, there will be three entry points to go to the coastal tourism location of Ujong Blang. The respondents' assessment of the aspects of the facilities at Ujong Blang beach is as shown below.

Table 2. Respondents' assessment on the facility aspects

\begin{tabular}{clc}
\hline No. & Variables & Score \\
\hline 1 & Road access & 329 \\
\hline 2 & Accommodation & 266 \\
\hline 3 & Sanitation facility & 213 \\
\hline 4 & Public open space condition & 225 \\
\hline 5 & Water recreation facility & 238 \\
\hline & Total & 1271 \\
\hline
\end{tabular}

Based on respondents' assessment, elements that had low scores on aspects of the facility were toilet facilities, conditions of public open space and water tourism facilities. It was because the presence of public toilets was inadequate. The public open space had not been arranged and the existing water tourism facilities in the form of speed boats and banana boats had not been maximized. For future development, according to Ujong Blang Village Head, the number of speed boats and banana boats will be added which will later be managed by Village-Owned Business Entities. At the moment, the existing speed boat belonged to the private community. In addition, some of the facilities that need to be added are public toilets and trash cans. This is in line with the theory of waterfront development that the waterfront 
functions as a place of recreation which must be supported by various facilities such as parks, fishing areas, riverwalks, amphitheater, diving, viewing post, shipping facilities, restaurants, and others [3]. In addition, some facilities that need to be added in are public toilets and trash cans. The cleanliness of the environment around the tourism area is the most important thing. The tourist area must be kept clean by not littering and maintaining cleanliness in public facilities. The behavior of littering and making the environment dirty will disturb tourists' comfort [7].

\subsection{Non-physical Aspects}

Non-physical aspects can be said to be related to things that are abstract and their effects can be felt indirectly at tourist sites. Non-physical aspects are related to security, comfort, social culture, and so on. In addition, tourist safety and comfort aspects are one of the factors that can determine the decision of tourists to visit a tourist attraction. One of the goals of visitors to tourist sites is to have recreation with family so that the convenience and security of tourist sites is important. The non-physical elements that become the assessment of this research were: security, comfort, safety, social and culture, and regional regulations in the research location. In general, the safety and comfort of Ujong Blang beach tourism sites was adequate, but improvement is needed, especially in the field of safety in the event of an accident to visitors. In terms of social and cultural aspects, the hospitality of the managers of tourist lodges on the coast of Ujong Blang was considered sufficient. The culture in the location is a fishing settlement where visitors can see typical activities in fisherman settlements such as when fishermen use traditional trawlers, fishermen fix nets and make wooden boats. The village of Ujong Blang Beach tourist location still imposes local norms, especially in the Aceh province, particularly where Islamic Sharia rules apply and no activities can lead to negative things or lifestyles. Norms are still applied in the society. This aims to create a polite and ethical lifestyle. The respondents' assessment of the physical aspects of the beach in Ujong Blang is shown in the table below.

Table 3.Respondents' assessment on non-physical aspects

\begin{tabular}{llc}
\hline No. & Variables & Score \\
\hline 1 & Security & 354 \\
\hline 2 & Comfort & 336 \\
\hline 3 & Safety & 203 \\
\hline 4 & Cultural attraction & 267 \\
\hline 5 & Regulation socialization & 273 \\
\hline & Total & 1433 \\
\hline
\end{tabular}

Based on respondents' assessment, the element that had low scores on non-physical aspects were the existence of facilities for safety for tourists and because there were no security posts from the SAR team (Search and rescue) at tourist site. There is a nearby community health center (puskesmas) facility 2 kilometers from the beach. Non-physical aspects of structuring waterfront tourism areas should be designed so that visitors feel safe and comfortable. Therefore, aspects of safety, security, comfort, and beauty need to be considered (Ridwan; 2010) [1]. Safety and comfort for tourists is one of the factors that determine the decision to make a trip to a tourism destination [7]. 


\section{Conclusion}

So far, waterfront tourism in Lhokseumawe City has not been managed as a whole. The area is still managed individually by tourism actors around the location. Therefore, support from the local government is needed to be able to improve regional development, especially with regard to infrastructure development. Based on the recapitulation of respondents' assessment of the three aspects of assessment, the physical aspects have the highest total score, the non-physical aspects are the second and the facility aspects are the lowest. Based on the respondents' assessment of the physical aspects, it is necessary to increase the elements of environmental and landscape management, and building arrangement. Landscape arrangement can be done by reforestation and vegetation so that the tourist site will be more beautiful. The low level of respondents' assessment of the environment is due to there was improperly disposed waste on the tourist site and the people low awareness to maintain cleanliness.

Table 4. Recapitulation of respondents' assessment of physical, facilities and non-physical aspects

\begin{tabular}{llll}
\hline No. & Aspects & Total & Score \\
\hline 1 & Physical Aspects & 1461 & 292.2 \\
\hline 2 & Facility Aspects & 1271 & 254.2 \\
\hline 3 & Non-physical Aspects & 1433 & 286.6 \\
\hline
\end{tabular}

If viewed from the aspect of facilities, the location of Ujong Blang beach is relatively close to the city center. There are accommodation facilities in Lhokseumawe city. The aspects of facilities that need to be improved are toilet facilities, water tourism facilities, and continued construction of roads on the coast of Ujong Blang. Whereas in the non-physical aspect, in general, it was already adequate, but improvements need to be done especially in the field of safety.The development plan of the Ujong Blang coastal tourism area needs to involve community leaders, youth leaders and stakeholders from villages crossed by the beach of Ujong Blang. This is so that development can be carried out smoothly, and the community can participate in the development of tourist site. Things that need to be improved are awareness in maintaining environmental cleanliness, continued road widening work which has not yet been completed (two lane roads), addition of public toilets, arrangement of green open spaces, increase in the number of tourist attractions, and improvement of safety facilities in the event of an accident for the visitor. On the location of Ujong Blang Beach, at the time of the research, there were no special spots like tourist area landmarks. Therefore, landmarks need to be bulit so that there are distinctive features in the tourist area. In other sectors, it is necessary to promote tourism with the implementation of tourist events conducted at the Ujong Blang Beach location. The Ujong Blang beach area is a traditional fishing settlement, so it can be used as an additional tourist attraction. There has been no local souvenirs in the area. However, there was local culinary called "Rujak" of Ujong Blang. It is expected that in the future there will be local souvenirs such as handicrafts. In 2016, Aceh Province received World 's Best Halal Cultural Destination and World' s Best Airline for Halal Travelers tours[8]. Receiving these awards is expected to strengthen the province of Aceh as a halal tourist destination that is worth a visit. This can be applied more thoroughly, not only in the provincial capital of Banda Aceh, but also to all tourist attractions in the province of Aceh. 


\section{References}

[1] Ginting, N, \& Wahid, J.: Exploring Identity's Aspect of Continuity of Urban Heritage Tourism. Procedia-Social and Behavioral Sciences, 202, 234-241 (2015)

[2] Steiner, F \& Butler, K.: Planning and Urban Design Standards. Canada: American Planning Association (2007)

[3] Breen, A \& Dick, R.: The New Waterfront, A Worldwide Urban Success Story, New York, Mc Graw Hill (1996)

[4] Sastrawati, I.: Prinsip Perancangan Kawasan Tepi Air (Kasus kawasan Tanjung Bunga), Jurnal Perencanaan Wilayah dan Kota Vol. 14 No. 3/Desember 2003: 95-117 (2003)

[5] Simamora, B.: Panduan Riset Perilaku Konsumen. Jakarta: PT Gramedia Pustaka Utama(2002)

[6] Badan Perencanaan Pembangunan Daerah Kota Lhokseumawe : Rencana Tata Ruang dan Wilayah Kota Lhokseumawe 2011-2031 (2011)

[7] Khalik, W.: Kajian Kenyamanan Dan Keamanan Wisatawan Di Kawasan Pariwisata Kuta Lombok, Jurnal JUMPA, Vol 10, No. 01, Juli 2014 (2014).

[8] Satriana, ED dan Faridah, HD.: Wisata Halal Perkembangan dan Tantangan, Journal of Halal Product and Research (JHPR) Vol. 01 No.02, Mei-November 2018 (2018) 